\title{
Blind to the Dignity of the Other: Obergefell v Hodges, Identity Oppression and the Deconstruction of Textualism and Originalism
}

\author{
Carter A. Wilson \\ Department of Political Science and Public Administration, Northern Michigan University, USA
}

Copyright $\bigcirc 2018$ by authors, all rights reserved. Authors agree that this article remains permanently open access under the terms of the Creative Commons Attribution License 4.0 International License

\begin{abstract}
While analyzing Obergefell (same sex marriage) and other select court decisions related to identity oppression (the oppression of groups identifiable by race, gender or sexual orientation), I demonstrate the limits of a traditional textualist and originalist approach and the advantages of a critical theory approach to legal analysis. Although I define both of these approaches, I focus on the application of critical theory to an analysis of Supreme Court decisions that sustain identity oppression. Critical theory focuses on the manner in which the dominant culture biases the decisions of Supreme Court judges against racial, gender and sexual orientation minorities. I illustrate that in Obergefell, both the dissenting and majority opinions applied a traditional textualist approach. However, the difference between the two opinions arose not from textualism but from the manner in which the dominant culture biased the judgment of the dissenters, distorted their concept of liberty and rights, and left them blind to the dignity of members of the identity group. Although I applaud the "new textualism," I argue that it does not go far enough. While focusing on methods of analysis, it pays too little attention to identity biases in the dominant culture. I argue that the dominant culture contains images, stories, ideas and assumptions about identity groups that diminish the dignity and humanity of their members. This culture operates to legitimize and normalize patterns of identity oppression. Although, there has been much progress in civil rights policies, this problem of the dominant culture persists in constitutional law today.
\end{abstract}

Keywords Critical Theory, Dominant Culture, Identity Oppression, Liberty, Originalism, Same Sex Marriage, Textualism

\section{Introduction}

While analyzing Obergefell (same sex marriage) and other court decisions related to identity oppression (the oppression of groups identifiable by race, gender or sexual orientation), I apply a critical theory approach. Throughout this essay, I attempt to accomplish five tasks.

First, I explain the critical theory approach. This approach focuses on the effect of the dominant culture on judicial decision-making. It is associated with critical race and critical feminist legal theory. It stands in contradistinction to the traditional approach to legal analysis. The traditional approach is associated with textualism and originalism.

Second, I apply a critical theory approach to an analysis of the Obergefell decision. I demonstrate that in Obergefell, both the dissenting and majority opinions applied a textualist/originalist approach. However, the difference between the two opinions did not arise entirely from different approaches to textualism/originalism. The difference arose as the dominant culture biased the judgment of the dissenters, distorted their concept of liberty and rights, and left them blind to the dignity of members of the identity group.

Third, I extend the critical theory approach to a review of select racial and gender cases. I argue that Supreme Court decisions that legitimized racial and gender oppression were not the simple and exclusive result of textualist/originalist methods of legal analysis. They were the result of the distorting effects of a dominant culture that blinded justices to the dignity of African Americans and women and biased justices' interpretation of the texts of the constitution and the intents of its authors. Indeed, judges' negative perceptions of members of minority groups shape judgments that enable and sustain patterns of identity oppression.

Fourth, I summarize the implications of the critical theory approach for understanding Supreme Court decision-making in identity oppression cases and the limits of textualism/originalism. Although I applaud the "new textualism," I identify the limits of this approach. I accept 
the importance of remaining faithful to constitutional texts. I agree with Jack Balkin's powerful critique of the type of conservative textualism and originalism promoted by Scalia and others. However, I argue that the new textualism does not go far enough. While focusing on methods of analysis, it pays too little attention to identity biases in the dominant culture.

Finally, I argue that the dominant culture contained images, stories and assumptions about identity groups that diminishes the dignity of their members and legitimizes patterns of identity oppression. Although, there has been much progress, this problem of the dominant culture persists in constitutional law today.

\section{Traditional Theory and Critical Theory}

The discipline of constitutional law is not much different from any other discipline. Like other disciplines, constitutional law suffers from a tension between the traditional theory approach and the critical theory approach.

The traditional theory approach places a premium on methodology. It assumes that the application of the best methods of research contributes to the discovery of bits and pieces of new knowledge that overtime contributes to the evolutionary progressive growth of the discipline. In the natural sciences, the traditional approach is skeptical. It involves the construction of hypotheses and the subjection of these hypotheses to rigorous tests designed to disprove and reject them.[1] The discipline of science advances through this rigorous process. Moreover, the scientific method involves the collection and measurement of data and the use of mathematical formulas. This approach is considered object, empirical and scientific.

The traditional legal theory approach to constitutional law focuses on methodology. Indeed, methodology is important in legitimizing Supreme Court decisions. As Philip Bobbit explains it in "The Age of Consent,"[2] if Supreme Court decisions are a function of whatever Supreme Court Justices claim, then these decisions could never be wrong. If they are exclusively a function of the values and political opinions of judges, then they could hardly be legitimate. It is the commitment to the text of the Constitution, the respect for the intent of its authors and the reverence for law that give court decisions legitimacy.

Today, there is a massive literature associated with the traditional legal theory approach. This literature has many branches and countless strands. Some of the branches include the science of law, legal positivism, legal realism, and formalism.[3] Others include judicial politics. [4] The most popular current version of traditional legal theory focuses on textualism and originalism.[5] There are many different forms of textualism and originalism. The late Justice Antonin Scalia has popularized a conservative approach to originalism. [6] Jack Balkin and others have popularized a more moderate or liberal version of textualism. [7] Nevertheless, this essay is not about textualism or originalism, two distinct traditional theory approaches. Although I contrast traditional textualism/originalism with critical theory, my focus in this essay is on the application of critical theory to an understanding of Supreme Court decisions that enable and legitimizes identity oppression.

Whereas traditional theory focuses on methodology, critical theory concentrates on ruling paradigms, controlling conceptual frameworks or dominant cultures that contain assumptions, expectations, images, and metaphors that shape perception and structure the understanding of phenomena in a discipline. Whereas methodology matters, critical theory identifies two major factors that advance a discipline: 1) the awareness and understanding of these paradigms, conceptual frameworks or cultures and 2) a shift from an old paradigm, conceptual framework or culture to a new one.

Max Horkheimer, Theodore Adorno and other scholars associated with the Frankfurt School's Institute for Social Research are often credited with originating this distinction between traditional and critical theory. In "Traditional Theory and Critical Theory," [8] Horkheimer distinguished critical theory from traditional theory. He characterized philosophical perspectives emerging during the Enlightenment era as "traditional theory." Traditional theory included the rationalism and skepticism of Descarte, the empiricism of Hobbes and Locke, and the rationalism and empiricism of Kant. [9]

Horkheimer, Adorno and others drew from Marx's theory of the role of the ideology of the dominant class in convincing all other classes that social, political and legal arrangements that privileged and enriched the dominant class were natural, inevitable and legitimate. Later Horkheimer, Adorno and other Frankfurt School scholars expanded this analysis beyond Marxist theory to include Weber, Freud and others.[10] This expanded theory included critiques of traditional approaches to philosophy, epistemology, natural science and the social sciences.

Critical theory insists that scholars do not approach the world with a blank screen upon which facts make impressions and mirror the world. Rather scholars approach the world with a framework or cultural context of preconceived views, assumptions and expectations about the world. They see, interpret and understand the world and facts through the prism of conceptual frameworks or cultural contexts.

In his classic book, The Structure of Scientific Revolutions, [11] Thomas Kuhn popularized this critical theory approach in the natural sciences. He demonstrated that advances in the natural sciences were not the result of the application of appropriate scientific methods that lead to new discovery, but the consequences of major shifts in scientific conceptual frameworks or paradigms. Kuhn 
argued that scientists do not approach the world with a blank mind and proceed to apply scientific methodology to advance scientific theory. Rather, scientists approach the world with well-developed paradigms. These paradigms contain preconceived assumptions and expectations about phenomena. Methodology is important to test the validity of an existing paradigm. However, Kuhn insists that scientific methodology does not produce revolutionary advances in science. Paradigm shifts do. The construction of new paradigms, new sets of assumptions and expectations of phenomena produced these advancements. Scientific methodology is bonded by paradigms. These methods have operated to validate existing paradigms. [12]

The problem of conceptual frameworks is more acute in the social sciences and law, as these conceptual frameworks are subject to the influences of the dominant culture. A dominant culture operates like a paradigm. Culture contains assumptions and expectations about the world. It provides an establish system of language and a scheme for classifying and defining things and phenomena. It contains set ways of categorizing people. It disseminates stories, images and expectations about different types of people.

These stories, images, and expectations embody values and evoke emotions. They provide fixed views about the role and position of different types of people in society. As much as researchers or judges claim to be unbiased and objective, a dominant cultures often bias judges and researchers in ways that they are often unaware. Critical theory is about understanding the role of the dominant culture in shaping the perceptions and influencing the decisions and judgments of legal scholars and judges. It is about recognizing that biases in legal and constitutional scholarship can be produced by a dominant culture or an established paradigm. [13]

\section{Critical Race Theory}

More recently, scholars have demonstrated that a dominant racist culture emerged simultaneously with the age of Enlightenment. This culture arose with conquest and slavery. It functioned to legitimize and normalize slavery, conquest, colonization and imperialism. [14] This racist culture prejudiced the perspectives of several eminent Enlightenment thinkers. In his classic book, Racist Culture: Philosophy and the Politics of Meaning, [15] David Goldberg demonstrates in detail how this racist culture biased the thinking of Enlightenment philosophers such Locke, Leibniz, Hume, Kant and others. As this racist culture characterized light skinned Europeans as morally and intellectually superior and darker skinned Africans as morally and intellectually inferior, so did many of the philosophers and scientists of this era. [16]

Critical race theory claims that this racist culture prejudiced Supreme Court judges and produced decisions that legitimized racial oppression. [17] Charles Lawrence sums it up:

Racism in America is much more complex than either the conscious conspiracy or a power elite or the simple delusion of a few ignorant bigots. It is a part of our common historical experience and, therefore, a part of our culture. It arises from the assumptions we have learned to make about the world, ourselves and others as well as from the patterns of our fundamental social activities. [18]

Critical race theory assumes that racism is not an incidental phenomenon. It is not simply an individual phenomenon manifested in a few uneducated individuals who join or support the Klan or Neo-Nazis. Racism is an integral part of the dominant culture. This culture influences perceptions and molds worldviews. It shapes and biases the decisions of Supreme Court judges. [19]

Critical feminist [20] and critical queer [21] theory hold similar assumptions. The dominant culture shapes Supreme Court decisions. Although the oppression of individuals identifiable as women, lesbian, gay, bi-sexual or transgender is fundamentally different from the oppression of individuals identifiable as black, there is one commonality, one similar factor. Throughout history, a dominant culture has operated to diminish the dignity and humanity of identity minorities. This culture has played a much larger role in shaping Supreme Court decisions that enabled this oppression. This point will emerge with a review of Obergefell and other select cases.

\section{Obergefell v Hodges: The Dissent}

The Obergefell v Hodges [22] decision was a hotly contested decision in which both the majority and the dissenting opinions claimed to be grounded in a strict reading of constitutional text and history. Writing separate dissenting opinions, Alito, Roberts, Scalia and Thomas all presumed to be textualists/originalists. None could see how fundamental rights and liberties were denied to gays and lesbians. Writing the majority decision, Kennedy also presumed to be a textualist/ originalist. He could see that the text of the due process clause of the Fourteenth Amendment prohibited governments from denying individuals liberty without due process of law. For Kennedy, not to see laws that specifically denied the most basic rights to gays and lesbians were to be blind to the dignity of gays and lesbians. The majority and dissenting opinions contradicted each other.

Alito, Roberts, Scalia and Thomas offered four separate dissenting opinions. Collectively, these four decisions emphasized these four main points:

(1) There is no constitutional right to same-sex marriage.

(2) The Constitution does not give the Court power to define the meaning of marriage. 
(3) The power to define marriage is reserved for the states.

(4) By extending the right of marriage to same sex couples, the majority opinion exceeded the Courts constitutional powers, undermined the democratic process, changed the definition of marriage, and disparaged deeply held religious beliefs about marriage.

Chief Justice Roberts concedes that the plaintiffs "make strong arguments rooted in social policy and considerations of fairness." [23] However, he insists that a strict reading of the text of the constitution, the intent of its authors and the context of well-established precedents would lead to the conclusion that there is no right to same-sex marriage and that the court has no power to create this right:

\begin{abstract}
Although the policy arguments for extending marriage to same-sex couples may be compelling, the legal arguments for requiring such an extension are not. The fundamental right to marry does not include a right to make a state change its definition of marriage. A state's decision to maintain the meaning of marriage that has persisted in every culture throughout human history can hardly be called irrational. [24]
\end{abstract}

The late Justice Scalia is more passionate in his dissent, "I write separately to call attention to this Court's threat to American democracy."[25] He argues that the majority opinion claims to be protecting liberty, but it robs the people of this nation of its liberty and subverts democracy.

Justice Thomas argues that the majority opinion fails to follow the original intent of the framers of the constitution and introduces a new concept of liberty foreign to any concept of liberty held by the Framers:

Since well before 1787 liberty has been understood as freedom from government action, not entitlement to government benefits. The Framers created our Constitution to preserve that understanding of liberty. Yet the majority involves our Constitution in the name of a "liberty" that the Framers would not have recognized, to the detriment of the liberty they sought to protect. Along the way, it rejects the idea-captured in our Declaration of Independence - that human dignity is innate and suggests instead that it comes from the government. [26]

Justice Alito joins Roberts, Scalia and Thomas in criticizing the majority of justices for undermining democracy and imposing a foreign and "distinctively postmodern" definition of liberty on the nation. He adds that the majority rejects the traditional definition of marriage and imposes a new definition the nation, against the will of the majority. [27]

\section{The Majority Opinion}

Writing for the majority, Justice Kennedy argues that this case is not about the Court creating a new definition of marriage and imposing it on the majority of Americans against their will, against their religion, against their commonsense and in ways that threaten democratic institutions. He adds that this case is about real people who suffered real harms by the actions of state governments. Obergefell v Hodges is a composite of about 14 different cases.

One case is about James Obergefell and his partner for over 20 years, John Arthur. In 2011, Arthur was diagnosed with amyotrophic lateral sclerosis (ALS), an incurable degenerative disease. Two years later James and Arthur decided to marry before Arthur died. They flew from their residence in Ohio to Maryland, where same-sex marriage is legal. They married. Arthur died a few months later. Ohio law prohibited the listing of James Obergefell as Arthur's surviving spouse. James sued the state of Ohio. [28]

Another case is about April De Boer and Jayne Rowse, two nurses who celebrated their permanent union in a ceremony in 2007. Shortly afterwards, they decided to adopt three children. However, Michigan law prohibits same sex couples from adopting children, but allows single mothers to adopt. Only one of the two could be listed as the legal parent. They sued the state of Michigan. [29]

For Kennedy, these cases are no more about the creation of a non-existing constitutional right to same-sex marriages than Loving v Virginia [30] was about the creation of a non-existing constitutional right to integrated marriages. These cases are about states denying a whole constellation of rights, benefits and freedoms to individuals because of their sexual orientation, just as Loving $\mathrm{v}$ Virginia was about states denying individuals a right to marriage because of race. Kennedy argues that the plaintiffs in this case did not seek to devalue or demean marriage. They revered marriage. They simply asked for the right to marry and the constellation of rights, benefits, privileges and freedoms that come with marriage:

These aspects of marital status include: taxation; inheritance and property rights; rules of intestate succession; spousal privilege in the law of evidence; hospital access; medical decision making authority; adoption rights; the rights and benefits of survivors; birth and death certificates; professional ethics rules; campaign finance restrictions; workers' compensation benefits; health insurance; and child custody, support, and visitation rules. [31]

Kennedy provides several reasons why marriage is a fundamental freedom or right. He says the "right to personal choice regarding marriage is inherent in the concept of individual autonomy." [32] The choice of a life-long intimate partner is a basis freedom inherent to the right to the pursuit of happiness. This choice shapes an 
individual's destiny. It defines the individual. Kennedy adds:

The nature of marriage is that, through its enduring bond, two persons together can find other freedoms, such as expression, intimacy, and spirituality. This is true for all persons, whatever their sexual orientation. [33]

Kennedy argues that the inability to see or respect these rights stem from a blindness to the dignity of gay and lesbian individuals. This blindness to the dignity of the other explains a long history of not just the denial of rights but the promotion of identity repression, evident in "law and widespread social conventions:" [34]

Same-sex intimacy remained a crime in many states. Gays and lesbians were prohibited from most government employment, barred from military service, excluded under immigration laws, targeted by police, and burdened in their rights to associate. [35]

\section{Distortions of Liberty, Rights and Dignity}

This decision involved competing conceptions of liberty, rights and dignity. The dissenting justices defined liberty as freedom from government action, minority rights as special rights or entitlements, and dignity as something innate to the individual and separate from government. The application of these definitions is problematic.

Scalia and Thomas insisted that liberty is "freedom from government action." The problem is not the definition, but its peculiar and problematic application. Indeed, these two Justices played a major role in threatening the liberty of gays. In Bower v Hardwick, [36] Scalia and Thomas supported a state of Georgia sodomy law that criminalized gay sexual acts. In their dissenting opinion in Lawrence $\mathrm{v}$ Texas,[37] they supported the constitutionality of a Texas law that prohibited sodomy, even when the police applied the law only against gay males. The imprisonment of gay men for engaging in consensual sexual acts in the privacy of their own homes is a clear case of government action denying individual liberty. Nevertheless, Scalia and Thomas are unable to see the problem with the application of their own definition of liberty, primarily because they cannot see that gay men are dignified citizens entitled to the same rights as any other citizens.

In Romer v Evans, [38] Scalia defended a state constitutional amendment enacted for the specific purpose of prohibiting local governments from protecting the rights of gays and lesbians. In defending this state constitutional amendment, Scalia redefined rights for minorities as special rights or entitlements. This redefinition trivialized minority rights. [39]

Thomas distorted the Enlightenment meaning of dignity. For the Enlightenment philosopher John Locke, in the state of nature all men had natural rights and equal dignity. Men established government and gave it the power to protect those rights and the responsibility to treat each person with equal dignity. Dignity is not something that a person must earn or inspire, nor is it reserved only for the deserving or the privileged. Recognizing the dignity of each individual is the responsibility of government. Thomas absolves government of this responsibility when he argues that dignity is innate and does not come from the government.

This practice of absolving government of the responsibility of treating each person with equal dignity is common in past decisions that have denied equal rights to women, African Americas, gays and lesbians. In his review of gender cases, Kennedy identifies this connection between equal dignity and equal rights:

Under the centuries-old doctrine of coverture, a married man and woman were treated by the State as a single, male-dominated legal entity....As women gained legal, political, and property rights, and as society began to understand that women have their own equal dignity, the law of coverture was abandoned. [40]

A critical review of gender and racial cases highlights and reinforces Kennedy's point.

\section{Gender Cases}

This critical review exposes the limits of the traditional textualist/originalist approach. Court decisions that legitimized identity oppression arose not from a strict reading of the text of the constitution but out of prejudices promoted by a dominant and biased culture. The following gender cases illustrate this point.

\section{Bradwell v Illinois}

Myra Bradwell was a legal scholar who passes the Illinois bar but was denied the privilege of practicing law because state law prohibited women from practicing law. She sued the state, arguing that the denial violated both the privilege and immunities and the equal protection clauses of the Fourteenth Amendment. [41]

The Court acknowledged that there were indeed privileges of citizenship, but denied that practicing law was one of them. The court rejected the equal protection claim on grounds that the Court had decided in the Slaughter House [42] cases that this clause pertained only to discrimination against African Americans.

In his concurring opinion, Justice Bradley displayed the most egregious examples of judicial prejudice against women masquerading as textualism/originalism:

On the contrary, the civil law, as well as nature herself, has always recognized a wide difference in the respective spheres and destinies of man and woman. Man is, or should be, woman's protector and defender. The natural and proper timidity and delicacy which 
belongs to the female sex evidently unfits it for many of the occupations of civil life. The constitution of the family organization, which is founded in the divine ordinance, as well as in the nature of things, indicates the domestic sphere as that which properly belongs to the domain and functions of womanhood. The harmony, not to say identity, of interest and views which belong, or should belong, to the family institution is repugnant to the idea of a woman adopting a distinct and independent career from that of her husband. So firmly fixed was this sentiment in the founders of the common law that it became a maxim of that system of jurisprudence that a woman had no legal existence separate from her husband; who was regarded as her head and representative in the social state; and notwithstanding some recent modifications of this civil status, many of the special rules of law flowing from and dependent upon this cardinal principle still exist in full force in most States. One of these is that a married woman is incapable, without her husband's consent, of making contracts which shall be binding on her or him. This very incapacity was one circumstance which the Supreme Court of Illinois deemed important in rendering a married woman incompetent fully to perform the duties and trust that belong to the office of an attorney and counselor.

It is true that many women are unmarried and not affected by any of the duties, complications, and incapacities arising out of married state, but these are exceptions to the general rule. The paramount destiny and mission of woman are to fulfill the noble and benign offices of wife and mother. This is the law of the Creator. And the rules of civil society must be adapted to the general constitution of things, and cannot be based upon exceptional cases. [43]

Bradley argued that if the state granted qualifying male citizens the privilege to practice law, it was not obligated to grant the same privilege to qualifying female citizens. Although he claimed his decision was based on a strict reading of the text of the Fourteenth Amendment and the intent of its authors, it reflected his prejudices. [44] He said that women were not suited for the practice of law; that they belonged in the home, as wives and mothers; that common law had made women subordinate to their husbands, with no legal existence apart from their husbands; and that common law prohibited women from entering into contracts or dealing with other legal matters. $\mathrm{He}$ argued that the privilege and immunities clause did not give women the right "to engage in any and every profession, occupation, or employment in civil life." [45] This opinion was based more on prejudice than on a strict reading of text.

\section{Minor v Happersett}

In this decision, Virginia Minor, president of the
Missouri branch of the National American Woman's Suffrage Association, sued for the right to vote. Like Bradwell, Minor argued that denying women the right to vote violated the privilege and immunity clause of the Fourteenth Amendment. The Court claimed that women were definitely citizens, but the right to vote was not a privilege of citizenship. However, the Court could not identify any of the privileges of citizenship. It just knew that voting was not one of them:

If the right of suffrage is one of the necessary privileges of a citizen of the United States, then the constitution and laws of Missouri confining it to men are in violation of the Constitution of the United Sates, as amended, and consequently void. The direct question is, therefore, presented whether all citizens are necessarily voters.

The Constitution does not define the privileges and immunities of citizens. For that definition we must look elsewhere. In this case we need not determine what they are, but only whether suffrage is necessarily one of them.[46]

The Court engaged in circular reasoning to deny women the right to vote. It argued that because women are citizens and are not allowed to vote, then voting cannot be a privilege of citizenship. This decision was not based on the text of the Constitution. It reflected the common prejudices of the period.

\section{Racial Cases}

This same problem of textualists/originalists reaching different conclusions exists in racial cases. The problem is that for centuries most Americans accepted the myth of textualism/originalism. Without much challenge, this myth assumed that when Supreme Court Justices rendered decisions that supported racial oppression these justices were simply adhering to the text of the constitution and the intent of its authors.

\section{Dred Scott v Sandford}

The Dred Scott v Sandford [47] illustrates this point. The traditional narrative of this decision is that Dred Scott was a slave who sued for his freedom but the Supreme Court denied his freedom after a careful reading of the constitution, which protected the institution of slavery. A full and careful reading of this decision explodes this myth and exposes the prejudices of the conservative Justices who supported this decision.

In writing the majority opinion, Chief Justice Taney projected explicit racial prejudices common in the Deep South unto both the words and the intent of the authors of both the Declaration of Independence and the U.S. Constitution. Taney took the words of the Declaration of Independence "all men are created equal" and insisted that 
these words meant only white men because Jefferson never intended to include black men. Taney says:

The language of the Declaration of Independence is equally conclusive: ...'We hold these truths to be self-evident: that all men are created equal; that they are endowed by their Creator with certain unalienable rights; that among them is life, liberty, and the pursuit of happiness...

The general words above quoted would seem to embrace the whole human family, and if they were used in a similar instrument at this day would be so understood. But it is too clear for dispute, that the enslaved African race were not intended to be included, and formed no part of the people who framed and adopted this declaration; for if the language, as understood in that day, would embrace them, the conduct of the distinguished men who framed the Declaration of Independence would have been utterly and flagrantly inconsistent with the principles they asserted; and instead of the sympathy of mankind, to which they so confidently appealed, they would have deserved and received universal rebuke and reprobation....[48]

For Taney, it was "too clear for dispute" [49] that the author of the Declaration of Independence did not intend to include African Americans. Taney used the same line of reasoning when dealing with the Preamble of the Constitution. In response to these explicit words found in the Preamble, "We the people of the United States," [50] he says:

The brief preamble sets forth by whom it was formed, for what purposes, and for whose benefit and protection. It declares that it is formed by the people of the United States; that is to say, by those who were members of the different political communities in the several States; and its great object is declared to be to secure the blessings of liberty to themselves and their posterity. It speaks in general terms of the people of the United States, and of citizens of the several States.

But there are two clauses in the Constitution which point directly and specifically to the negro race as a separate class of persons, and show clearly that they were not regarded as a portion of the people or citizens of the Government then formed.[51]

When confronted with the text of the Preamble of the Constitution and the Declaration of Independence, Taney simply claimed that the words do not mean what they say.

The traditional narrative of this decision ignores the extent to which Chief Justice Taney dehumanized African Americans. Critical legal theorist Leon Higginbotham provides an excellent summary of the extent to which Chief Justice Taney was blind to the dignity of African Americans:
In the opinion, Chief Justice Taney made twenty-one references to African Americans as inferior and to whites as dominant or superior. Chief Justice Taney referred to African Americans as an "inferior class of beings," an "unfortunate race," a "degraded" and "unhappy" race, "unfit to associate with the white race," excluded from civilized Governments and the family of nations," "far below [whites] in the scale of created beings," "held in subjection and slavery, and governed [by the dominant race] at their own pleasure," "separated from white[s] by indelible marks," "impressed [with] deep and enduring mars of inferiority and degradation," and "separated and rejected.'[52]

Taney made no distinction between free African Americans and enslaved African Americans. He dehumanized and stigmatized all African Americans. It was neither the text of the constitution nor the intentions of its authors that justified the denial of any and all constitutional rights of African Americans. It was Taney's blindness to the dignity of African Americans. Taney was infected by contemporary prejudices. These prejudices shaped his interpretation of both the text and the intentions of its authors.

There is another problem with the traditional narrative of Dred Scott. Both liberals and conservatives scholars accept the fact that the Constitution protected the institution of slavery. Consequently, many scholars accept as valid Taney's assumption that African Americans were not part of the larger political community in the new nation. However, in his book, The Right to Vote: The Contested History of Democracy in the United States, Alexandar Keyssar demonstrates that after the ratification of the Constitution only three of the thirteen states barred African Americans from voting.[53] Racism and the exclusion of blacks from political communities intensified after the invention of the cotton gin, after the emergence of cotton as a major cash crop that supported a large part of the national economy, and after a series of horrifying slave revolts. At the time of the Dred Scott decision, the nation was intensely polarized over both the slave issue and the race issue. The point is that the intense and egregious racism exhibited by Taney was an integral part of Southern culture in the 1850s. It was not the norm during the ear of the American Revolution and the early years of the nation. Although infected with racism in his later life, Thomas Jefferson did not share Taney truly venomous and invidious racism.

\section{U.S. v Cruikshank (1876)}

In the United States v Cruikshank [54] the Court struck down the sections of the 1870 Enforcement Act which outlawed organized racist violence and made it a federal offense for groups like the Red Shirts or the Ku Klux Klan to murder blacks for racially motivated reasons. This case 
emerged out of the 1873 Colfax, Louisiana massacre. Nine whites were arrested and convicted of mass murder. The Court overturned the conviction and nullified the provision of the Enforcement Act pertaining to $\mathrm{Ku}$ Klux Klan violence. The Court claimed that Congress had exceeded it powers under the Constitution and had encroached into state jurisdiction. Justice Bradley added:

The main ground of objection is that the act is municipal in its character, operating directly on the conduct of individuals, and taking the place of ordinary state legislation' and that there is no constitutional authority for such an act inasmuch as the state laws furnish adequate remedy for the alleged wrongs committed.[55]

The Reconstruction Amendments were added to the Constitution with the specific intent to free the slaves and to extend to them the same rights and privileges given to anyone else: the right to vote, the right to life, liberty and property, and the right to have the government protect these rights, as the government protected the rights of others. Section 5 of the Fourteenth Amendment reads: "The Congress shall have power to enforce by appropriate legislation, the provisions of this article." [56] The text of this section explicitly expanded federal powers to protect the persons and property of African Americans. Since this text was ratified in 1866, it trumped the Tenth Amendment (ratified in 1791) which contained the reserve powers clause. The court ignored Section 5 of the Fourteenth Amendment which expanded federal powers over the states. As many members of the Red Shirts became members of Southern state militias, the Court left African Americans to the mercy of racial violence. This decision was not based on a strict reading of constitutional text or the intent of its authors. It expressed a profound blindness to the dignity of African Americans and an intense contempt for their persons and property.

\section{The Civil Rights Cases of 1883}

The Civil Rights Cases of 1883 [57] decision struck down The Civil Rights Act of 1875. This decision involved four different cases, all involving racial exclusion in public accommodations. Two cases involved the exclusion of African Americans from theaters; one involved the barring of African Americans from the Grand Opera House in New York.

Another case involved the ejection of an African American woman from a passenger railroad car, reserved for whites only. The conductor claimed he believed the African American woman was a prostitute because she was accompanied by a young white male. The young white male was her nephew. Her husband, who happened to be white, sued the railroad company under the Civil Rights Act of 1875. During the trial, the judge accepted as a reasonable assumption the racist belief that a black woman accompanied by a white man is most likely a prostitute. The court rejected as irrelevant any claim that the assumptions of the conductor or the lower court judges were prejudiced, as the court found the Act itself unconstitutional. [58]

The Court ruled the Civil Rights Act unconstitutional on several grounds. First, the court insisted that the law was enacted under the Fourteenth Amendment and that this Amendment restricted state behavior, not individual behavior. Second, the law violated the reserved powers clause of the Tenth Amendment. Third, the Court insisted that the issue involved the regulation of private theatres, restaurants, and other private establishments and that these establishments should be regulated by local ordinances, not by the federal government.

Writing the majority opinion, Justice Waite dismissed without much discussion the argument that racial segregation constituted a badge of slavery offensive to the Thirteenth Amendment. He insisted that slavery had to do with forcing people to work and that excluding people by force from public accommodations was totally unrelated to slavery. [59]

In his dissenting opinion, Justice Harlan pointed out that the federal Fugitive Slave Act prohibited both individual and state action. Moreover, private establishments rely on state and local police to enforce racial segregation. [60]

These decisions were grounded in neither texts nor precedents. They were shaped by a court that had accepted racial segregation as rational, that was blind to the dignity of African Americans, and that was committed to promoting a racially segregated society.

\section{Plessy v Ferguson}

The Civil Rights Cases of 1883 set the stage for Plessy v Ferguson. [61] In Plessy, the court further trivialized the significance of the Thirteenth and Fourteenth Amendments and underscored the "separate but equal" principle. This principle was established in the City of Boston v Roberts [62] decision during the era of slavery, almost two decades before the ratification of the Reconstruction Amendments. The court rejected without comment the notion that racial segregation constituted a "badge of slavery" in violation of the Thirteenth Amendment.

Writing the majority opinion, Justice Brown argued that those who oppose state mandated segregation have a problem not with legal equality, but with social equality. $\mathrm{He}$ maintained that social inequality arises from racial differences that the law is powerless to eradicate. He added, "If one race be inferior to the other socially, the Constitution of the United States cannot put them upon the same plane." [63] He insisted that African Americans felt diminished or offended by racial exclusion, "not by reason of anything found in the act, but solely because the colored race chooses to put that construction upon it." [64] However, he accepts the argument that if a white passenger 
is forced to move to the colored car, that move would damage the white passenger's reputation: Specifically he said:

If he be a white man and assigned to a colored coach, he may have his action for damages against the company for being deprived of his so-called property. Upon the other hand, if he be a colored man and be so assigned, he has been deprived of no property, since he is not lawfully entitled to the reputation of being a white man. [65]

Justice Brown's argument can be simplified: blacks are socially inferior and therefore it is reasonable to separate them from whites. If a white person is placed in the colored car, that white person's reputation is tarnished. Brown believes that whites are to be treated with dignity. Brown is blind to the dignity of African Americans.

Textualists/originalists like Scalia, Thomas, Roberts and Alito are blind to three aspects of these civil rights cases: dignity, government action, and liberty. The denial of rights and privileges to minority groups that are given to majority groups arise out of blindness to the dignity of the members of the minority group. Moreover, norms that deny the right to vote, the liberty to choose an intimate partner, or the freedom to enter public space open to majority groups are all enforced by government action and police powers.

\section{Brown v Board of Education}

Today, Brown v Board of Education is settled law. Nevertheless, this decision illustrates the limits of the traditional textualist/originalist approach. Four different textualist/originalist approaches to this decision has yielded four different and contradictory conclusions.

First, Southern political leaders used a textualist/originalist approach to assault the Brown decision. This textualist/originalist assault was best expressed in the Southern Manifesto [66], a document signed by 19 Southern Senators and 82 Representatives. Published just after the announcement of the decision, the Manifesto insisted that Brown was a gross abuse of judicial powers and that the Court had violated the constitution, specifically the Fourteenth Amendment and the Tenth Amendment. The Manifesto argued that the Congress that authored the Fourteenth Amendment had been responsible for segregating the public schools in Washington DC: "The very Congress which proposed the amendment subsequently provided for segregated schools in the District of Columbia." [67] It added that all the states that ratified the Fourteenth Amendment had laws on the books mandating segregation. It urged states to exercise their constitutional rights by legally resisting the forced integration of the schools. It maintained that the federal government had no legal or constitutional right to impose the Brown decision on Southern states:
We regard the decision of the Supreme Court in the school cases as a clear abuse of judicial power. It climaxes a trend in the federal judiciary undertaking to legislate, in derogation of the authority of Congress, and to encroach upon the reserved rights of the States and the people. [68]

Second, conservative scholars used a textualist/originalist approach to defend the Brown decision. Contradicting the Southern Manifesto's use of textualism/originalism to assault Brown, the late Justice Scalia used this approach to defend Brown. Scalia insisted that Justice Harlan was correct in his dissent in the Plessy decision, that the constitution is colorblind and that laws that exclude individuals on the basis of color violate the constitution. Scalia argued that an originalist interpretation of the Thirteenth and Fourteenth Amendments would have validated the Brown decision and overturned Plessy. He made this point passionately in a 1990 dissenting opinion:

In my view the Fourteenth Amendment's requirement of "equal protection of the laws," combined with the Thirteenth Amendment's abolition of the institution of black slavery, leaves no room for doubt that laws treating people differently because of their race are invalid. Moreover, even if one does not regard the Fourteenth Amendment as crystal clear on this point, a tradition of unchallenged validity did not exist with respect to the practice in Brown. To the contrary, in the $19^{\text {th }}$ century the principle of "separate-but-equal" had been vigorously opposed on constitutional grounds, litigated up to this Court, and upheld only over the dissent of one of our most historically respected Justices. [69]

Scalia made this point again in his books on originalism. [70] He accepted Harlan's analysis that the authors of the Thirteenth and Fourteenth Amendments intended to for the Constitution to be colorblind. However, Scalia does not comment on Harlan's advocacy of white supremacy and black inferiority.

Third, mainstream progressive textualist/originalist legal scholars reject Scalia's argument. [71] They see Brown as rejecting the textualist/originalist approach and disregarding precedents, but making the right decision. [72] For example, drawing from Jack Balkin's "tripartite theory of citizen," Robert Turner argues that Congress identified three different forms of rights: civil rights, political rights and social rights. [73] Civil rights entailed contract, property ownership and court access rights. Political rights included the right to vote and serve on juries. Social rights consisted of the right to marry a person of another race and to attend a racially integrated school. Turner insists that the members of Congress who created the Thirteenth and Fourteenth Amendments never intended to protect social rights. He argues that the Reconstruction Congress supported segregated schools and never intended for the Fourteenth Amendment to protect social rights. Proponents 
of this position support the Brown decision not because it was consistent with the text of the Constitution or the intent of its authors, but because it was the right decision. It was fair, equitable and progressive. It advanced both the Constitution and constitutional law. [74]

A fourth perspective suggests that the Reconstruction Amendments were products of an anti-racist social movement that emerged with an ascending subordinate progressive culture antithetical to the dominant racist culture and anathema to the Southern culture that advocated white supremacy, sustained the institution of slavery and produced the Jim Crow system of black oppression. According to this perspective, the authors of these amendments believed in the dignity of all individuals, regardless of skin color. These authors were fundamentally opposed to state laws that mandated racial exclusion or segregation and that denied individuals' basic rights and liberties, including the liberty to marry whomever they loved. [75]

Proponents of this fourth perspective draw from two compelling factors. First they cite the ideas, values, arguments and visions expressed by the authors of the Reconstruction Amendments. Second, they underscore the bills written and supported by the majority of the members of the Congress that produced these Amendments.

James Ashley, U.S. Representative from Northwest Ohio, wrote the Thirteenth Amendment. Prior to the Civil War, Ashley was an activist and abolitionist in the anti-slavery constitutionalist movement. He broke from other abolitionists like William Garrison who believed that the U.S. Constitution supported slavery. Ashley argued that a true textualist reading of the Constitution with the Declaration of Independence would render slavery unconstitutional. He maintained that slavery violated the principles of the equality and dignity of every enslaved individual. Slavery violated natural rights and human rights, protected by the Constitution and the Declaration of Independents. Most scholars disagree with Ashley. However, when he wrote the Thirteenth Amendment he intended for it to do more than free enslaved persons. He expected it to restore their rights and liberties under the Constitution. He wrote Section 2 of this Amendment to expand federal powers over state governments. He expected the federal government to protect the natural and human rights of formally enslaved persons. He opposed state mandated segregation. [76]

U.S. Representative John Bingham wrote Section One of the Fourteenth Amendment. In support of this Amendment he stated:

To all such I beg leave again to say, that many instances of State injustice and oppression have already occurred in the state legislation of this Union, of flagrant violations of the guarantied privileges of citizens of the U.S., for which the national government furnished and could furnish by law no remedy whatever. Contrary to the express letter of your Constitution, 'cruel and unusual punishments' have been inflicted under state laws within this union upon citizens, not only for crimes committed, but for sacred duty done, for which and against which the Government of the United Sates had provided no remedy and could provide none. [77]

Bingham made it clear in strong, unambiguous language that this Amendment was designed to trump the Tenth Amendment, to preempt the reserved powers of the states, and to increase federal powers to protect the civil rights of African Americans. [78] Like other supporters of the Fourteenth Amendment in Congress, Bingham viewed rights of citizenship and civil rights broadly to include human rights and natural rights. [79]

Some supporters of this Amendment were civil rights activists who supported integration. Prior to the Civil War, Senator Charles Sumner was a civil rights attorney. He represented Benjamin Roberts in the City of Boston $\mathrm{v}$ Roberts decision. Robert's daughter, who was black, was denied admission to a public school that was open only to whites. Sumner lost this case as the Massachusetts Supreme Court ruled that racially segregated school were valid under the state constitution so long as the separate schools were equal. Sumner supported a political movement to change the Massachusetts Constitution to prohibit state mandated racially segregated schools. This movement was successful in 1855. Indeed, Sumner devoted much of his life promoting civil rights and opposing state mandated racial segregation. [80]

Representative Thaddeus Stevens was so passionate in his promotion of racial integration that when he died he was buried in an all-black grave yard in order to continue in death, the crusade for racial integration that he had pursued in life. The inscription on his tombstone reads:

I repose in this quiet and secluded spot

Not from any natural preference for solitude

But, finding other Cemeteries limited as to Race by Charter Rules

I have chosen this that I might illustrate in my death The Principles which I advocated through a long life: EQUALITY OF MAN BEFORE HIS CREATOR [81]

Whereas it is true that all black schools were established during the Reconstruction era, these schools were created by black educators to remedy a problem created by antebellum Southern laws that outlawed the teaching of slaves to read. Black educators created special black schools to remedy the damage caused by these laws. These black educators, though supported by Congress, were not promoters of state mandated racially segregated schools. Historian McQuirter notes:

When Washington briefly became a federal territory in 1871, African American men continued to make important decisions for the city. Lewis H. Douglass introduced the 1872 law making segregation in public 
accommodations illegal. But in 1874, in part because of growing black political power, the territorial government was replaced by three presidentially appointed commissioners. [82]

State mandated segregation did emerge in Washington, D.C. as the Manifesto claimed, but after the Reconstruction period. It was not the product of the same political culture and political leaders that produced the Fourteenth Amendment.

Proponents of this fourth perspective insist that the Congress that produced the Reconstruction Amendments opposed racial segregation. The Civil Rights Act of 1875 illustrates this point. This law explicitly prohibited racial segregation in public accommodations. Of course, critics of this fourth perspective concede this point. However, these critics add that this bill neglected to prohibit racial segregation in public schools, indicating that the authors of the Fourteenth Amendment did not intend for the Amendment to prohibit racially segregated schools.

Proponents of this fourth perspective reject this criticism. These proponents argue that the majority of the members of Congress who approved the Fourteenth Amendment indeed supported a law to prohibit state mandated racial segregation in public schools. A section of the original bill included this provision. In 1870, Charles Sumner introduced this bill, which included a section that prohibited racial segregation in public education. The passage of this bill involved a clash of political cultures: an ascending civil rights culture committed to the equal dignity and rights of all individuals and a racist culture infected with hostility and contempt toward blacks and beliefs in white supremacy and black moral and intellectual inferiority. Opposing this bill, Representative Milton Durhim (D-Kentucky) said that this bill will incite "a war of the races, [in which] the black race in this country will be exterminated."[83] This bill was stalled in Congress for about five years. After the death of Sumner and in honor of him, it passed the Senate in 1874 by a wide margin, 29 yes, 19 no votes. [84] However, support in the House for this Civil Rights bill diminished after the defeat of over 60 Republicans. The recession of 1873, reduced public support for civil rights and raised concerns over the economy. However, the point is that an anti-racist culture produced the Thirteenth and Fourteenth Amendments and the authors of these Amendments never intended for it to be used to support state mandated public schools. [85]

Initially, racist Southerners opposed the Fourteenth Amendment as an illegal Amendment because it passed Congress after legitimately elected Southern leaders were expelled from Congress. This opposition disappeared after the Slaughter-House [86] decision. A Supreme Court dominated by Justices operating under the racist culture interpreted the Fourteenth Amendment so narrowly that most civil rights protections disappeared.

\section{Shelby v Holder}

Issues of racial oppression were not limited to the $19^{\text {th }}$ and $20^{\text {th }}$ century Supreme Court decisions. Blindness to the dignity of others persists in $21^{\text {st }}$ century civil rights cases. This blindness is most evident in the Shelby v Holder [87] decision. In this decision, the Supreme Court struck down Section 4 of the Voting Rights Act of 2006. Section 5 of the Voting Rights Act required federal permission before counties were allowed to change voting related laws. Section 4 applied Section 5 preclearance requirement exclusively to select Southern states. Writing for the majority, Chief Justice Roberts notes that conditions have changed that required this law. He insists that the South today is not the same as the South prior to the passage of the 1965 Voting Rights Act. He insists that Southern states are no more likely to engage in racially motivated voting discrimination than Northern states. He concludes that Section 4 departs "from the principle that all States enjoy equal Sovereignty" and that this extraordinary provision is no longer justified in the $21^{\text {st }}$ century. [88]

Justice Thomas writes a passionate concurring decision. He insists that blatant racial discrimination is rare today and Section 4 now encroaches the sovereignty of Southern states and is no longer justifiable:

Today, our Nation has changed. "[T]he conditions that originally justified [\$5] no longer characterize voting in the covered jurisdictions." Ante, at 2. As the Court explains: " "[V]oter turnout and registration rates now approach parity. Blatantly discriminatory evasions of federal decrees are rare. And minority candidates hold office at un-precedented levels.' [89]

Although he did not write a concurring opinion, the late Justice Scalia was quite vocal during oral arguments. In response to the near unanimous vote in Congress in support of the renewal of the Voting Rights Act in 2006, Scalia says:

And this last enactment, not a single vote in the Senate against it. And the House is pretty much the same. Now I don't think that's attributable to the fact that it is so much clearer now that we need this. I think it is very likely attributable to a phenomenon that is called perpetuation of racial entitlement. It's been written about. Whenever a society adopts racial entitlements, it is very difficult to get out of them through the normal political process.

I don't think there is anything to be gained by any Senator to vote against continuation of this act. And I am fairly confident it will be reenacted in perpetuity unless-unless a court can say it does not comport with the Constitution. You have to show, when you are treating different states differently that there's a good reason for it. [90]

Two disturbing issues stand out in Scalia's treatment of 
civil rights cases. The first issue is his treatment of the fundamental rights of minorities. In this Shelby case, he refers to rights as racial entitlements. Scalia's statement suggests that the right of African Americans to vote is not a fundamental right, but an entitlement, a term that has become a euphemism for welfare, an undeserved hand out from government. For Scalia, this right has become a perpetual, undeserved hand-out. He believes it is perpetual because people are too afraid of opposing these handouts for fear of being labeled a racist. Scalia's re-categorization of fundamental rights as entitlements not only trivializes these rights. It is a profound expression of contempt for the rights and for the people making claims to these rights.

Scalia re-categorized the fundamental rights of gays and lesbian in Romer v Evans. [91] He refers to laws that prohibit discrimination on the basis of sexual orientation as a special right, like an undeserved right, undergirded by contempt for the group making the claim to this right to government protection.

The other disturbing issue is Scalia's contradictory use of democracy. In Obergefell, Scalia castigates the majority for nullifying the democratic decision of state governments, decisions that denied fundamental rights to gays and lesbians. In Shelby, Scalia invalidated a federal law enacted via the federal democratic process, pursuant under powers granted to the federal government by the Fifteenth Amendment to protect the fundamental voting rights of African Americans. Scalia privileged state laws over federal laws. However, in McDonald v City of Chicago, [92] Scalia supported the Court striking down a Chicago ordinance that restricted gun ownership. The overriding legal principle is that the democratic rights of white males in control of state governments take precedence over the civil and human rights of women, gays, lesbians and African Americans and other racial minorities. Moreover, even the democratic majority in Congress is subordinate to the states' rights of white male majorities. Whereas Scalia prides himself as a die-heart textualist/originalist, his decisions are not the result of a strict reading of the text of the Constitution or the intent of its authors. Like many biased Justices of the past, his decisions are more of a function of his unconscious biases than a strict reading of the constitution.

The decision of the majority in Shelby contradicts the facts of the case. Written by Justice Ginsburg, the dissenting opinion underscores these contradictions. She insists that between 1982 and 2005, the state of Alabama had been found in violation of Section 2 of the Voting Rights Act more times than any other state in the union. She adds, "In other words, even while subject to the restraining effect of Section 5, Alabama was found to have 'denied or abridged' voting rights 'on account of race or color' more frequently than nearly all other States in the Union." [93] She identified several cases that had reached federal appeal courts and two that had reached the Supreme Court. In Hunter v Underwood the Supreme Court "struck down a provision of the Alabama Constitution that prohibited individuals convicted of misdemeanor offenses "involving moral turpitude from voting." [94] In Pleasant Grove v U.S., the Supreme Court decided that "Pleasant Grove-a city in Jefferson County, Shelby's County's neighbor - engaged in purposeful discrimination by annexing all-white areas while rejecting the annexation requests of the adjacent black neighborhood." [95] Ginsburg present direct evidence of racial discrimination motivated by explicit and expressed racial prejudice:

A recent FBI investigation provides a further window into the persistence of racial discrimination in state politics. See United States v. McGregor, 824 F. Supp. 2d 1339, 1344-1348 (MD Ala. 2011). Recording devices worn by state legislators cooperating with the FBI's investigation captured conversations between members of the state legislature and their political allies. The recorded conversations are shocking. Members of the state Senate derisively refer to African-Americans as "Aborigines" and talk openly of their aim to quash a particular gambling-related referendum because the referendum, if placed on the ballot, might increase African-American voter turnout. Id., at 1345-1346 (internal quotation marks omitted). See also id., at 1345 (legislators and their allies expressed concern that if the referendum were placed on the ballot, " '[e]very black, every illiterate' would be 'bused [to the polls] on HUD financed buses' "). These conversations occurred not in the 1870's, or even in the 1960's, they took place in 2010. Id., at 1344-1345. The District Judge presiding over the criminal trial at which the recorded conversations were introduced commented that the "recordings represent compelling evidence that political exclusion through racism remains a real and enduring problem" in Alabama. Id., at 1347. Racist sentiments, the judge observed, "remain regrettably entrenched in the high echelons of state government."'[96]

These recent episodes forcefully demonstrate that $§ 5$ 's preclearance requirement is constitutional as applied to Alabama and its political subdivisions. [97]

\section{Summary}

Traditional theory focuses on methods. Although there are countless variations of the methods of traditional textualist/originalist theory in law, this theory focuses on the text of the Constitution and its authors. Progressive textualists see the Constitution as a living document that grows and adjusts to contemporary problems and issues. They see this Constitution as committed to justice.

In contrast to traditional theory, critical theory sees a dominant culture operating in ways that diminishes the dignity and humanity of individuals identifiable by race, gender, sexual orientation, religion or ethnicity. Although 
there has been much progress in constitutional law, particularly with the end of the Jim Crow era, the legalization of same-sex marriage, and the advances in women's rights, problems persist with a dominant culture that marginalizes individuals identifiable by race, gender, and sexual orientation. There is a contradiction between the notion of a just constitution and the persistence of identity oppression.

Nowhere is this contradiction more striking and evident than in the area of criminal justice. Despite a constitution committed to justice, the United States incarcerates a large proportion of its minority population than any other country in the world [98]. The U.S. is one of the very few developed nations that continue to execute people. Originalist justices like Justice Scalia supported the constitutionality of the death penalty, despite considerable evidence that capital punishment is carried out in a racially discriminatory manner.[99] Originalist supported the practice of sentencing child offenders as young as 13, 14, 15 and 16 years ago to life imprisonment without any chance of parole, despite the fact that a disproportionately number of these children are African American. [100] Prior to the Miller v Alabama decision, human rights organizations like Amnesty International and Human Rights Watch had cited the United States for violating the human rights of these offenders. [101] Originalist justices allow federal and state governments to deny public benefits and privileges to citizens because of prior convictions, despite the fact that a disproportionately high percentage of those denied benefits are African Americans. These benefits and privileges include public housing, student loans, voting rights, food support and others. Michelle Alexander refers to this process of denying benefits as "the new Jim Crow." [102]

Throughout the $19^{\text {th }}$ and $20^{\text {th }}$ centuries and continuing into the $21^{\text {st }}$ century, conservative textualist/originalist had insisted that conservative Supreme Court Justices deliver decisions based on some objective, politically neutral method. There were many different and sometimes inconsistent methods such as a adhering to a strict reading the text of the constitution, the intentions of its authors, the meaning of text at the time of the writing of the text, well established doctrines or precedents established by past decisions or some other principles. Even if these decisions appeared to be unfair to minorities, the traditional theory that focused on methods suggests that these unfair decisions arose out of a commitment to the integrity of the constitution. A corollary of this tradition is that liberal justices deviate from the constitution as they attempt to solve contemporary problems. Indeed, Chief Justice Roberts expressed this corollary when he suggested in the Obergefell decision that the majority opinion made "strong arguments rooted in social policy and considerations of fairness."[103]

A critical review of select Supreme Court decisions exposes problems with this traditional textualist/originalist theory. This review demonstrates that far from adhering to the text of the constitution, conservative justices distorted the meaning of the text and the intentions of its authors. (Of course, Scalia was less concern with these intentions.) Conservative justices in the Post-Reconstruction Court enabled the denial of rights to women and African Americans not by a strict reading of the text. These justices read and understood texts within the context of a dominant culture that diminished the humanity and dignity of women and African Americans. They ignored language in the Thirteenth, Fourteenth and Fifteenth Amendments that explicitly expanded federal powers to protect the rights of African Americans. They disregarded the intentions of the authors of these Amendments to circumvent states' rights, because Southern state governments deliberately denied rights to African Americans. These justices were not only blind to the dignity of African Americans. In many cases, they exhibited contempt and hostility toward African Americans.

Traditional textualist/originalist theory ignores the distorting effect of a dominant political culture. Culture consists of established language, world-views, stories, images, and assumptions about the world and groups of people. Culture focuses attention, filters information and shapes perception. In cases involving identity oppression, the dominant culture functions to normalize dehumanizing or denigrating views of the oppressed. This dominant culture portrays women as naturally unsuitable to the practice of law, African Americans as socially undesirable, and gays and lesbians as abnormal.

\section{REFERENCES}

[1] See Karl Popper, The Logic of Scientific Discovery (New York: Routledge, 1959/2000).

[2] P. Bobbitt, "The Age of Consent," The Yale Law Journal, 123: 2334 (2014).

[3] For an overview of the science of law see H. Schweber, "The "Science of Legal Science: The Model of the Natural Sciences in the Nineteenth-Century American." Legal Education 17: 3, (Fall 1999).

https://wwwweb.archive.org/journals/1hr/17.3/schweber.ht $\mathrm{ml}$. For a good summary of legal positivism see R. George, The Autonomy of Law: Essays on Legal Positivism (Oxford: Clarendon Press, 1996). For a discussion of legal realism see W. Fisher III, M. Horwitz, and T. Reed eds. American Legal Realism (New York: Oxford University Press, 1993). For legal formalism see B. Leiter, "Legal Formalism and Legal Realism: What Is the Issue?" Legal Theory 16: 2, 111-133. See also F. Schauer, Formalism, Yale Law Journal, 97, 509-548, (March 1988).

[4] See R. Posner, How Judges Think (Cambridge: Harvard University Press, 2010) and R. Dworkin, A Matter of Principle (Cambridge: Harvard university Press, 1986). 
Both Posner and Dworkin recognize the politics of judicial decision-making. However, Dworkin see judges as more constrained by legal context (statute, constitution, and precedents) than Posner. However, beyond the legal constraints, judges have some discretion. Politics arise from the realm of discretion. The perspectives of Posner and Dworkin differ little from Benjamin Cardozo's classic characterization of the judicial process. However, Cardozo recognized the biasing effect of culture; even though not comment on identity biases in the dominant culture. See B. Cardozo, The Nature of the Judicial Process (New Haven: Yale University Press, 1921).

[5] I am tempted to define textualsim as a focus on the text or words of the constitution and the general meaning of these words; originalism as a focus on the original intent of the authors of the text; and strict constructionism as a strict adherence to the text of the constitution. However, there are many different definitions of these terms in the literature. Justice Scalia has been defined as an originalist. Nevertheless, he states, "What I look for in the Constitution is precisely what I look for in a statute: the original meaning of the text, not what the original draftsmen intended." Quoted from A. Scalia, A Matter of Interpretation: Federal Courts and the Law (Princeton: Princeton University Press, 1997).

[6] Scalia, A Matter of Interpretation. A. Scalia, "Originalism: the Lesser Evil," University of Cincinnati Law Review. (1989). A. Scalia and B. Garner, Reading Law: The Interpretation of Legal Texts (St. Paul, MN: Thomson/West, 2012). See also R. Bork, The Tempting of America: The Political Seduction of the Law (New York: Touchstone, 1991).

[7] J. Balkin, Living Originalism (Cambridge: Harvard university Press, 2011). D. Whittington, "The New Originalism," Georgetown Journal of Law and Public Policy 22, 2 (2004). T. Colby and P. Smith Living Originalism. Duke Law Journal 59: 239 (2009).

[8] M. Horkheimer, "Traditional and Critical Theory," in M. O'Connell ed. Critical Theory: Selected Essays (New York: Continuum Press, 1937/1999).

[9] M. Horkheimer and T. Adorno, Dialectics of Enlightenment, Translated by E. Jephcott (Stanford: Stanford University Press, 1947).

[10] See E. Fromm, Escape From Freedom (New York; Holt 1941/1965). E. Fromm, Beyond the Chains of Illusion: My Encounters with Marx and Freud (New York: Open Road, Integrated Media). T. Adorno, E. Frenkel-Brunswik, Daniel Levison and N. Sanford, The Authoritarian Personality (New York: Harper \& Row 1950 and W.W. Norton \& Company, 1993). Herbert Marcuse, One Dimension Man (. Marcuse provides a direct critique of logical positivism. Fromm discusses how changes in social, economic and historical conditions produce changes in the dominant culture and character type. Adorno et al focus on the authoritarian character type and its predisposition to racial, gender and sexual orientation biases. For a more recent literature on the authoritarian orientation see B. Altemeyer Right-Wing Authoritarianism (University of Manitoba Press, 1981); K. Stenner, The Authoritarian Dynamic (New York: Cambridge University Press, 2005); and M. Hetherington and J. Weiler, Authoritarianism and Polarization in American Politics (New York: Cambridge University Press, 2009).
[11] T. Kuhn, The Structure of Scientific Revolutions (Chicago: University of Chicago Press, 1996).

[12] Ibid.

[13] R. Unger, The Critical Legal Studies Movement (New York: Verso, 2015).

[14] A. Smedley and B. Smedley, Race in North America: Origin and Evolution of a Worldview (Boulder, Colorado: Westview Press, 2012).

[15] D. Goldberg, Racist Culture: Philosophy and the Politics of Meaning (Cambridge: Blackwell Publishers, 1993).

[16] Ibid. Goldberg states: Kant's remarks about 'Negroes' and their position in relation to his moral theory need to be read against the general discourse of racialized subjects that define the Enlightenment. 'Savages' are wanting in 'moral understanding', and 'Negroes' in Kant's view are the most lacking of all 'savages'. As a moral rationalist Kant turned Hume's empiricist endorsement of racial subordination into an a priori principle: So fundamental is the difference between [the Negro and White] races of man, and it appears to be as great in regard to mental capacities as in color... The blacks are vain in the Negro way, and so talkative that they must be driven apart from each other by thrashings. (I. Kant, Observations on the Feeling of the Beautiful and the Sublime. Translabed by J. Goldthwait (Berkeley: University of California Press, 1960).

[17] D. Bell, And We Are Not Saved: The Elusive Quest for Racial Justice (New York: Basic Books, Inc., 1984). R. Delgado ed. Critical Race Theory: The Cutting Edge (Philadelphia: Temple University Press, 1995. K. Crenshaw, N. Gotanda, G. Peller and K. Thomas, Critical Race Theory: The Key Writings that Formed the Movement. R. Delgado and J. Stefanic, Critical Race Theory: An Introduction (New York: New York University Press, 2017). I. Lopez, White By Law: The Legal Construction of Race (New York: New York Press, 2006).

[18] C. Lawrence, "The Id, the Ego and Equal Protection: Reckoning with Unconscious Racism," Stanford Law Review 39 (1987), quoted in Bell, And We are Not Saved.

[19] Although critical theory makes this claim (Bell, Delgado, Lawrence, Crenshaw and others), other non-critical theory approaches make this same assumption about racial prejudices in the courts. For example, L. Mills, A Penchant for Prejudice: Unraveling Biuas in Judicial Decision Making (Ann Arbor, MI: University of Michigan Press, 1999). Mills demonstrates the pervasiveness of implicit racial biases in court decisions. She insists that implicit biases persist because judges are resistant to acknowledging them. Studies from the neuroscience demonstrate the presence of implicit biases. See D. Amodio, "The Neuroscience of Prejudice and Stereotyping. Nature Reviews Neuroscience 15 (2014).

[20] See K. Barlett and R. Kennedy ed. Feminist Legal Theory: Readings in Law and Gender (Boulder, Colorado: Westview Press, 1991). N. Dowd and M. Jacobs, Feminist Legal Theory: An Anti-Essentialist Reader (New York: New York University Press, 2003).

[21] See J. Mogul, A. Ritchie and K. Whitlock, Queer (In)Justice: The Criminalization of LGBT People in the United States (Boston: Beacon Press, 2011). 
[22] Obergefell $v$ Hodges, 576 U.S. (2015)

[23] Ibid.

[24] Ibid.

[25] Ibid.

[26] Ibid.

[27] Ibid.

[28] Ibid.

[29] Ibid

[30] Loving v Virginia, 388 U.S. 1, (1967).

[31] Obergefell

[32] Ibid.

[33] Ibid.

[34] Ibid.

[35] Ibid.

[36] Bower v Hardwick, 478 U.S. 186, (1986).

[37] Lawrence v Texas, 539 U.S. 558, (2003).

[38] Romer v Evans, 517 U.S. 620, (1996).

[39] Ibid.

[40] Obergefell, 2015.

[41] Bradwell v Illinois, 83 U.S. 130, (1873).

[42] Slaughter-House Cases, 83 U.S. 36, (1873).

[43] Bradwell.

[44] In analyzing Bradwell, the form of textualism or originalism matters. A strict reading of the text of the "privileges" clause would favor extending rights to women. However, public attitudes during this era did not favor extending rights to women. The issue of the rights and dignity of women was raised in Congress during debates over this Amendment. Senators like Henry Wilson, Richard Yates, Benjamin Wade, Charles Sumner and others favored women's rights. However, most were fearful that pushing too hard for women's rights would reduce support for the Amendment. See W. Nelson, The Fourteenth Amendment: From Political Principle to Judicial Doctrine (Cambridge: Harvard University Press, 1988). Also, John Bingham conceded that coverture limited women's rights. See J. Bingham, "One Country, One Constitution, and One People," Speech of Honorable John A. Bingham of Ohio, in the House of Representatives, February 28,.1866. https:archive.org/stream/onecountryonecon00bing/onecoun tryonecon00bing_bjvu.txt.

[45] Bradwell.

[46] Minor v Happersett, 88 U.S. 162, (1875).

[47] Dred Scott v Sandord, 60 U.S. 393, (1857).

[48] Ibid.

[49] Ibid.
[50] Ibid.

[51] Ibid

[52] L. Higginbotham, Shades of Freedom: Racial Politics and the Presumptions of the American legal Process, vol. II (New York: Oxford University Press, 1996), 65-66.

[53] A. Keyssar, The Right to Vote: The Contested History of Democracy in the United States (New York: Basic Books, 2000).

[54] U. S. v Cruikshank, 92 U.S. 542, (1876).

[55] Ibid.

[56] U.S. Constitution, Fourteenth Amendment, Section 5, (1866).

[57] Civil Rights Cases of 1883, 109 U.S. 3, (1883).

[58] Higginbotham, Shades of Freedom.

[59] Civil Rights Cases of (1883).

[60] Ibid

[61] Plessy v Ferguson, 163 U.S. 537, (1896).

[62] City of Boston v Roberts, 59 Massachusetts 198, (1850).

[63] Plessy v Ferguson.

[64] Ibid.

[65] Ibid.

[66] "The Southern Manifesto," Time Magazine. March 26, 1956. This document was known formally as "The Declaration of Constitutional Principles."

[67] Ibid.

[68] Ibid.

[69] Rulan v Republican Party of Illinois, 497 U.S. 62 (1990). Quoted in R. Turner, "A Critique of Justice Antonin Scalia's Originalist Defense of Brown v Board of Education," University of California Law Review, 62: 170 (2014).

[70] A. Scalia Originalism: The Lesser Evil, University of California Law Review, 57 (1989). A. Scalia, A Matter of Interpretation: Federal Courts and the Law (Princeton: Princeton University, 1997). A. Scalia and B. Garner, Reading Law: The Interpretation of Legal Texts (St. Paul, MN: Thomson/West, 2012).

[71] J. Balkin, Living Originalism (Cambridge: Harvard University Press, 2011). M. Klarman, From Jim Crow to Civil Rights: The Supreme Court and the Struggle for Racial Equality (New York: Oxford University Press, 2004). R. Turner, "A Critique of Justice Antonin Scalia's Originalist Defense of Brown v Board of Education." K. Whittington, "The New Originalism," Georgetown Journal of Law and Public Policy 2 (2004).

[72] Ibid

[73] R. Turner, "A Critique of Justice Antonin Scalia's Originalist Defense of Brown v Board of Education."

[74] J. Balkin, Living Originalism. 
[75] I develop this perspective from several sources: $M$. McConnell, "The Fourteenth Amendment: A Second American Revolution or the Logical Culmination of the Tradition?" Loyola Law Review 25:4 (1992). M. McConnell, "The Forgotten Constitutional Moment," University of Minnesota Law School 11:1 (Winter 1994). W. Nelson. The Fourteenth Amendment: From Political Principle to Judicial Doctrine (Cambridge: Harvard University Press, 1988). R. Zietlow, "The Ideological Origins of the Thirteenth Amendment," Houston Law Review 49:2 (2012).

[76] R. Zietlow, "The Ideological Origins of the Thirteenth Amendment."

[77] John Bingham, Congressional Register, (1866). Quoted in Horace Flack. "The Adoption of the Fourteenth Amendment. Dissertation, (Baltimore: Johns Hopkins University, 1908). Also quoted in Michael K. Curtis. No State Shall Abridge: The Fourteenth Amendment and the Bill of Rights. (Durham, Norther Carolina: Duke University Press, 1986), 87.

[78] J. Bingham, "One Country, One Constitution, and One People," Speech of Honorable John A. Bingham of Ohio, in the House of Representatives, February 28, 1866. https:archive.org/stream/onecountryonecon00bing/onecoun tryonecon00bing_bjvu.txt.

[79] W. Nelson, The Fourteenth Amendment. Nelson adds, "Republicans like John A. Bingham imprecisely conflated "the rights of citizenship with "the sacred rights of human nature" not because they were careless, but because they understood that the demands of higher law overlapped or, perhaps, even coincided with the rights of citizens living under a republican form of government.' (p. 72).

[80] A.-M. Taylor, Young Charles Sumner and the Legacy of the American Enlightenment, 1811-1851 (Boston: University of Massachusetts Press, 2001). D. Donald. Charles Sumner and the Coming Civil War (New York: Alfred A. Knopt, 1960).

[81] www.historicalmarkerproject.com/markers/HM10Y3_steve ns-grave-memorial_Lancaster-PA.html.

[82] M. McQuirter, "A Brief History of African Americans in Washington, D.C.: 1800-1975. www.culturaltourismdc.org/portal/a_brief_of_african_amer icans_in_wiashington_dc.

[83] Congressional Record, House, $43^{\text {rd }}$ Congress, $1^{\text {st }}$ Session, January 6, 1874, 406.

[84] R. McConnell, “The Forgotten Constitutional Moment.”

[85] Ibid.
[86] The Slaughter-House Cases 83 U.S. 36 (1873).

[87] Shelby v Holder, 570 U.S. (2015).

[88] Ibid.

[89] Ibid.

[90] A. Scalia, Official Transcripts, U.S. Supreme Court, Shelby County, Alabama v Eric Holder, No. 12-96, 2013, 47. Supremecourt.gov/oral_arguments/arguments_transcripts/1 2-96.pdf.

[91] Romer v Evans

[92] McDonald v City of Chicago, 561 U.S. 743, (2010).

[93] Shelby $v$ Holder

[94] Hunter v Underwood 471 U.S. 222, (1985).

[95] Pleasant Grove v U.S. 479 U.S. 462, (1987).

[96] Shelby $v$ Holde.r

[97] Ibid.

[98] P. Enns, Incarceration Nation: How the United States Became the Most Punitive Democracy in the World (New York: Cambridge university Press, 2016). See also, Alexander, The New Jim Crow. The United States Department of Justice, national Institute of Correction, World Prison Population List/Eleventh Edition states, "There are more than 10.35 million people incarcerated throughout the world with the most being in the United States-more than 2.2 million. Seychelles has the highest prison population rate in the world with 799 per 100,000 of its total population. It is followed by the United States (698)." However, A. Nellis, "The Color of Justice: Racial and Ethnic Disparity in State Prisons," (Washington, D.C.: The Sentencing Project, June 14, 2016) notes that the black incarceration rate in the United States is 1,408 per 100,000 .

[99] McClesky v Kemp 481 U.S. 279 (1987).

[100] Miller v Alabama 567 U.S. 460 (2012).

[101] Amnesty International/Human Rights Watch, "For the Rest of Their Lives: Life without Parole for Child Offenders in the United States," (Amnesty International/Human Rights Watch, 2005).

[102] Alexander, The New Jim Crow.

[103] Obergefell v Hodges 